\title{
EXPERIMENTAL AND MATHEMATICAL MODELING STUDY FOR SOLAR DRYING OF MINT
}

\author{
${ }^{1}$ Sameh, S. Kishk; ${ }^{2}$ Solaf, S. Abd El-Reheem and ${ }^{3}$ Ramadan, A. ElGamal
}

\begin{abstract}
Mint plant was dried using greenhouse solar dryer. Two of the forced convection operating modes (continuous and intervals) were used and compared with the open sun drying method. The drying kinetics of mint (Mentha spicata L.) in terms of moisture content, moisture ratio, drying time and drying rate was investigated. The continuous forced convection mode gives the highest drying rate for mint than the interval mode and open sun drying. The drying data of solar and open sun drying of mint were fitted to ten thin layer drying models and the Modified Henderson and Pabis model satisfactorily described the drying behavior of mint with highest $R^{2}(0.99)$ and lowest $P$ and RMSE values than other models. The results of the study are very useful for commercial scale drying of mint to optimize the drying process and to achieve a superior quality dried product.
\end{abstract}

\section{INTRODUCTION}

$\mathrm{M}$ int leaves can be used as a medicinal and aromatic plant. It helps in colds, flu, fever, poor digestion, food poisoning, rheumatism, motion sickness, hiccups, stings, earaches, flatulence and for throat and sinus ailments (Akpinar, 2010). Because of high moisture content (78-85\%, w.b), mint is ordinarily dried for market, in order to slow microbial growth and biodegradation and to reach a final product with an effectively increased shelf life (Tarhan et al., 2010; Sallam et al., 2015). Also, drying brings about a substantial reduction in weight and volume, minimizing packaging, storage, and transportation costs (Doymaz, 2006; Kadam and Samuel, 2006). Drying is the most common method of medicinal plant preservation and due to high investment and energy costs, drying is also a large expense in medicinal plant production.

1, 3 Lecturer of Agric. Eng. Dep., Fac. of Agric., Suez Canal Univ., 41522 Ismailia, Egypt.

2 Researcher at the Ag. Eng. Res. Inst (AEnRI), Giza

Misr J. Ag. Eng., October 2018 
Product quality and consequently earnings are significantly influenced by the drying regime. Hot air drying has some common problems such as poor rehydration characteristics and loss of nutrients (Kocabiyik et al., 2014). Generally, increasing the temperature and velocity shortens the drying time. However, for heat-sensitive products, such as food and pharmaceutical products high temperature decreases product quality (Kumar et al., 2015). Essential mint oils are retained to a greater extent when plants are dried under ambient conditions, compared to sun drying or forced air. Essential oil composition and quality are greatly influenced by oven drying temperature. About $75.7 \%$ of essential oils are lost during oven drying at $60^{\circ} \mathrm{C}$ than at $30^{\circ} \mathrm{C}$ (Baydar and Erbas, 2009). In most developing countries such as Egypt, the conventional sun drying technique for agricultural products is traditionally performed by spreading the produce on an open floor/field under the sun for a period of time and until the desired level of moisture content is reached (Kishk et al., 2019). However, the contamination with dust, soil, sand particles, and insects are some problems associated with this method (Sallam et al. 2015; Sreekumar et al., 2008). Besides being labor- and time-intensive method, uncontrolled sun drying is usually accompanied with nutritional degradation, flavor and color changes and reduction of functionality (Rabha et al., 2017). To overcome previous problems, solar drying method could be used to dry agriculture products instead of traditional sun drying method as the drying process takes place in enclosed structures (El-Sebaii et al., 2002). Using solar energy in the drying process reduces the use of fossil fuels (coal, gas, and oil) leading to a reduction in pollutant emissions (Santos et al., 2005). Solar drying as a mean of food preservation has been considered one of the most promising venues for utilization of solar energy (Sekyere et al., 2016). The use of solar dryers significantly reduces drying time and prevents mass losses; furthermore, product quality can be improved compared to traditional sun drying methods. Utilization of solar energy as a reliable energy source to dry foods in Egypt has a great potential, as, the annual daily average solar radiation on a horizontal plane in Egypt is $8 \mathrm{kWm}^{-2}$ day $^{-1}$ and the measured annual average daily sunshine duration is approximately $11 \mathrm{~h}$ (El-Beltagy et al., 2007). Thin layer drying is widely used for agricultural 
products to prolong their shelf life. Among the wide range of models, thin layer drying models have found widest application because of their ease of use. They do not require evaluation of many models parameters as is common in more complex representations (Kadam et al 2011). Several researches have investigated the drying kinetics of mint leaves and evaluated various mathematical models to describe thin layer drying characteristics (Soysal, 2005; Doymaz, 2006; Özbek and Dadali, 2007; Akpinar, 2010; Kadam et al., 2011). In Egypt, the mint is usually marketed as a whole plant. However, the literature is scarce on the drying kinetics of mint as a whole plant especially in greenhouse dryers. Sallam et al. (2015) studied the drying behavior of the whole mint plant in direct and indirect solar dryers under natural and forced convection modes. They found that results indicated that drying of mint under different operating conditions occurred in the falling rate period, where no constant rate period of drying was observed. As mentioned above, the literature is scarce on the drying kinetics of mint as a whole plant especially in greenhouse solar dryer. Besides, most previous studies used small scale dryers in their investigations. Accordingly, this study aimed to investigate the drying kinetics of mint as a whole plant using pilot scale greenhouse solar dryers considering the effect of the forced convection operation mode (continuous and intervals). In addition, ten mathematical models were used to fit the drying curves of mint.

\section{MATERIALS AND METHODS}

In this study, greenhouse dryer used to dry mint plant and compared with the traditional sun drying method. Two greenhouse dryers were built and operated by two modes of forced convection. One unit operated by continuous forced convection where the air pump operated continuously during the drying period, while the other unit operated by the interval mode where the air pump connected with an electronic timer to be operated every 15 minutes ( 15 min ON/ 15 mint OFF). The performance of two modes compared with the open sun drying.

\section{Greenhouse solar dryer construction}

Two identical plastic greenhouse dryers were designed, built and installed on the roof of the Agricultural Engineering Department at Suez Canal University (latitude of $30.62^{\circ}$, longitude $32.27^{\circ}$ and $5 \mathrm{~m}$ above sea level) 
during October 2018. As shown in Figs (1 and 2) the geometric shape of the greenhouse type solar dryer was Quonset established on an iron base of gross dimensions ( $2.0 \mathrm{~m}$ long, 1.0 wide, and $0.9 \mathrm{~m}$ high). The dryer has a drying chamber with a gross dimension of 2.0 long, 1.0 wide, and $0.1 \mathrm{~m}$ high and a door of $0.75 \times 0.45 \mathrm{~m}$ located at the front side of the dryer for loading, unloading and collecting samples of mint during the drying process. The solar dryers were covered by a single layer of polyethylene sheet of $50 \mu \mathrm{m}$ thick and with effective transmittance of $91 \%$. To maintain the durability of the structural frame of plastic greenhouses and prevent pad side effects of wind load on the polyethylene cover, ten tensile compacted plastic wires ( $2 \mathrm{~mm}$ diameter) were tied and fixed throughout the walls. The solar dryers were orientated in the East-West direction to maximize the intensity of the solar radiation. A perforated wire was fixed at $15 \mathrm{~cm}$ over the bottom of the greenhouses forming a plenum chamber under the wire netted floor. Each solar dryer is equipped with a centrifugal fan model (SMB-10, USA) with a power of $0.75 \mathrm{hp}$ electric motor and equipped with an inverter to control the fan air flow rate. A PVC pipe with a diameter of $5.08 \mathrm{~cm}$ was used to carry out the air from the dryer to the outside. An open window with a surface area of $0.053 \mathrm{~m}^{2}$ (0.35 $\mathrm{m}$ long and $0.15 \mathrm{~m}$ wide) was positioned at the top of the opposite side of the suction fan position for air intake through each dryer. Drying air was cycled through the solar dryer which continuously had a hot air heated by solar energy. The drying air was continuously introduced from the top position of the solar dryer and leaves through the bottom position under the drying chamber via the suction fan. The air fan of one greenhouse unit connected with an electronic timer to be operated by the interval mode ( $15 \mathrm{~min}$ ON/ $15 \mathrm{~min}$ OFF). The air flow rate was adapted to be $45 \mathrm{~m}^{3} \mathrm{~h}^{-1}$ in both greenhouse dryers. 


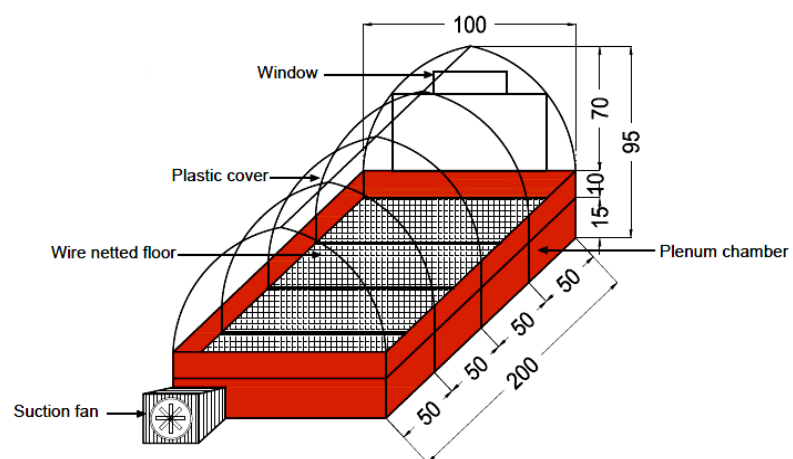

Fig. (1): Schematic diagram of the solar dryer

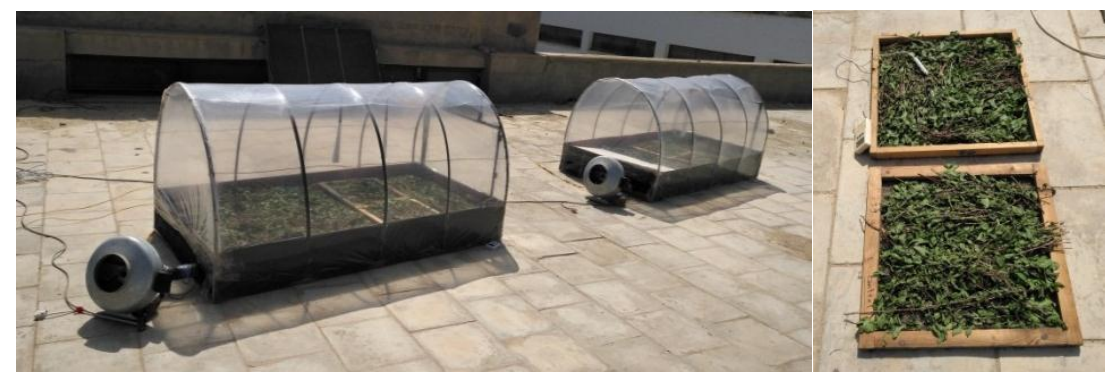

Fig. (2): Quonset shape greenhouse type solar dryer and traditional sun drying of mint

\section{Samples preparation and experimental setup}

Fresh mint was purchased from the local market in Ismailia, Egypt. Before drying, the foreign materials, as weeds, spoiled and discolored plants were removed. The initial moisture content of mint samples was determined by drying the mint samples (10 g, in duplicate) in an electric oven at $70{ }^{\circ} \mathrm{C}$ until reaching a constant weight as recommended by (AOAC, 1990). The average initial moisture content of fresh mint was found to be $85 \%$ w.b. Before the experiment, the mint samples were distributed uniformly on six trays with a dimension of $0.5 \times 0.5 \mathrm{~m}$. Each tray loaded by about $800 \mathrm{gm}$ of fresh mint with distribution about 3.2 $\mathrm{kgm}^{-2}$. The trays used in this study to easily record the weight losses of samples during drying. For traditional sun drying method, two trays with mint samples placed under the open sun (Fig. 2). The other four trays placed in the greenhouse dryers (two trays for each unit. Then, the remained area of the greenhouse dryers was loaded with mint samples 
distributed uniformly over the surface of the perforated wire net of each dryer as shown in Fig. (2). The density of mint samples was adapted to be the same as on the trays $\left(3.2 \mathrm{~kg} \mathrm{~m}^{-2}\right)$. The experimental work was run for 10 hours continuously through the period from 7 am to $5 \mathrm{pm}$, solar time. During the experimental work, an electrical digital balance (BS-Series, China) with an accuracy of $0.001 \mathrm{~g}$ was used to determine the mass of wet and dry samples to calculate moisture content. The weight of the samples was measured just before conducting the drying test and periodically (each hour) during the drying process (Mwithiga and Olwal, 2005).

\section{Data accusation and measurements}

The meteorological data included the solar radiation flux incident on a horizontal surface, wind speed and direction, air temperature and the air relative humidity were obtained from the meteorological station (Vantage Pro 2, Davis, USA) which was located beside the greenhouse dryers. The air temperature and relative humidity inside the dryer were measured periodically during the drying process. Relative humidity was measured using a digital thermo-hygrometer data logger (Prime Capsule/HT-165, Australia) with an accuracy of $( \pm 1 \%)$. Air temperature inside the solar dryers was measured by k-type thermocouples. The thermocouples were connected to a data-logger system (Lab-Jack logger, USA) to display and record the data during the experimental work. The output data were recorded every ten minutes and averaged every hour. Three thermocouples were functioned to measure the indoor air temperature for each greenhouse. The inlet and outlet air temperatures were measured using four thermocouples. The velocity of drying air was measured using digital anemometer (MT- 4005, Korea) with measuring range up to $30 \mathrm{~ms}^{-1}$ and accuracy of $\pm 0.1 \mathrm{~ms}^{-1}$. The air flow rate was adapted to be $45 \mathrm{~m}^{3} \mathrm{~h}^{-1}$ in both greenhouse dryers.

\section{Mathematical modeling of drying curves}

Mathematical modeling is essential to predict and simulate the drying behavior. It is also an important tool in dryer's design, contributing to a better understanding of the drying mechanism. The experimental drying data for mint were fitted to ten thin layer drying models listed in Table (1) by using nonlinear least squares regression solved by a Quasi-Newton numerical method. The moisture ratio (MR) in these models is defined as: 


$$
M R=\frac{M_{t}-M_{e}}{M_{0}-M_{e}}
$$

Where, $\mathrm{M}_{\mathrm{t}}$ is moisture content at any time of drying ( $\mathrm{kg}$ water $/ \mathrm{kg}$ dry matter), $\mathrm{M}_{\mathrm{e}}$ is the equilibrium moisture content ( $\mathrm{kg}$ water $/ \mathrm{kg}$ dry matter), and $\mathrm{M}_{0}$ initial moisture content $(\mathrm{kg}$ water $/ \mathrm{kg}$ dry matter). However, a simplified form of equation 1 for calculation the moisture ratio (in the form of $\left.M R=M_{t} / M_{0}\right)$ was considered in this study for mathematical modeling of the solar drying curves due to the continuous fluctuation of the relative humidity of the drying air during solar drying (Kishk et al., 2019). The coefficient of determination $\left(R^{2}\right)$, mean relative percent error (P) and root mean square error (RMSE) obtained for these equations were then used to compare the relative goodness of fit of experimental data. These parameters can be calculated as follows:

$$
\begin{aligned}
& P=\frac{100}{N} \sum_{i=1}^{N} \frac{\left|M R_{\text {exp }, i}-M R_{\text {pre }, i}\right|}{M R_{\text {exp }, i}} \\
& R M S E=\sqrt{\frac{1}{N} \sum_{i=1}^{N}\left(M R_{\text {exp }, i}-M R_{\text {pre }, i}\right)^{2}}
\end{aligned}
$$

where $\mathrm{MR}_{\text {exp,i }}$ is the ith experimentally observed moisture ratio, $\mathrm{MR}_{\text {pre, }}$ is the ith predicted moisture ratio and $\mathrm{N}$ is the number of observations (Kishk et al., 2019). The best model describing the drying behavior of mint was chosen as the one with the highest value of $\mathrm{R}^{2}$ and the lowest values of $\mathrm{P}$ and RMSE.

Table (1): Mathematical models widely used to describe the drying kinetics.

\begin{tabular}{rlll}
\hline \hline S.N. & Model & Model equation & References \\
\hline \hline 1 & Newton & $M R=\exp (-k t)$ & Erbay and Icier (2010) \\
2 & Page & $M R=\exp \left(-k t^{n}\right)$ & Gürlek et al. (2009) \\
3 & Logarithmic & $M R=a \exp (-k t)+c$ & Hacihafizoğlu et al. (2008) \\
4 & Two-term & $M R=a \exp (-k o t)+b \exp (-k l t)$ & Corrêa et al., 2012 \\
& Two-term & $M R=a \exp (-k t)+(1-a) \exp (-$ & Sharaf-Elden et al. (1980) \\
5 & exponential & $k a t)$ & Henderson and Pabis \\
6 & Henderson and Pabis & $M R=a \exp (-k t)$ &
\end{tabular}


PROCESS ENGINEERING

Table (1): Mathematical models widely used to describe the drying kinetics.

\begin{tabular}{|c|c|c|c|}
\hline S.N. & Model & Model equation & References \\
\hline & & & (1961) \\
\hline 7 & $\begin{array}{l}\text { Modified Henderson } \\
\text { and Pabis }\end{array}$ & $\begin{array}{l}M R=a \exp (-k t)+b \exp (-g t)+c \\
\exp (-h t)\end{array}$ & Akpinar (2010) \\
\hline 8 & Wang and Singh & $M R=1+a t+b t^{2}$ & Wang and Singh (1978) \\
\hline 9 & $\begin{array}{l}\text { Approximation of } \\
\text { diffusion }\end{array}$ & $\begin{array}{l}M R=a \exp (-k t)+(1- \\
\text { a) } \exp (-k b t)\end{array}$ & Yaldız and Ertekin (2001) \\
\hline 10 & Verma et al. & $M R=a \exp (-k t)+(1-a) \exp (-g t)$ & Verma et al. (1985) \\
\hline
\end{tabular}

Where $\mathrm{a}, \mathrm{b}, \mathrm{c}$, and $\mathrm{n}$ are drying constants, $\mathrm{k}$ drying coefficient $\left(\mathrm{h}^{-1}\right)$ and $\mathrm{t}$ is the time $(\mathrm{h})$

\section{RESULTS AND DISCUSSION}

\section{Weather conditions and temperature data}

The weather conditions during open sun and solar drying of mint plant are shown in Fig. (3). During the drying experiments, the temperature and the relative humidity of the ambient air ranged from 22 to $29^{\circ} \mathrm{C}$ and from 47 to $67 \%$. The solar radiation ranged from 75 to $590 \mathrm{Wm}^{-2}$ and the wind speed from 0.21 to $0.92 \mathrm{~ms}^{-1}$ as shown in Fig. (3). As usual, the ambient air temperature and solar radiation reached the highest values between 11:00 AM and 1:00 PM, whereas the relative humidity reached the lowest values during the same period. Fig. (3) also show that the temperature values of drying air inside the greenhouse dryers operated by both continuous (CSD) and intervals (ISD) modes were almost the same. The temperature values ranged from 30 to $48^{\circ} \mathrm{C}$. The interval mode showed fluctuation in the air temperature inside the greenhouse dryer. When the air fan closed (off mode $15 \mathrm{~min}$ ) the temperature increased inside the greenhouse dryer and when the air fan opened (run mode $15 \mathrm{~min}$ ) the air passed away and temperature decreased inside the greenhouse dryer.

\section{Drying characteristics of mint}

Fresh mint plant used in the drying experiment with initial moisture content of $85 \pm 1$ w.b. ( $5.8 \mathrm{Kg}$ water $/ \mathrm{Kg}$ dry matter). The variation in the weight of the product as a function of time was followed. The changes in the moisture contents per amount of the dry matter of mint with time are shown in Fig. (4). 


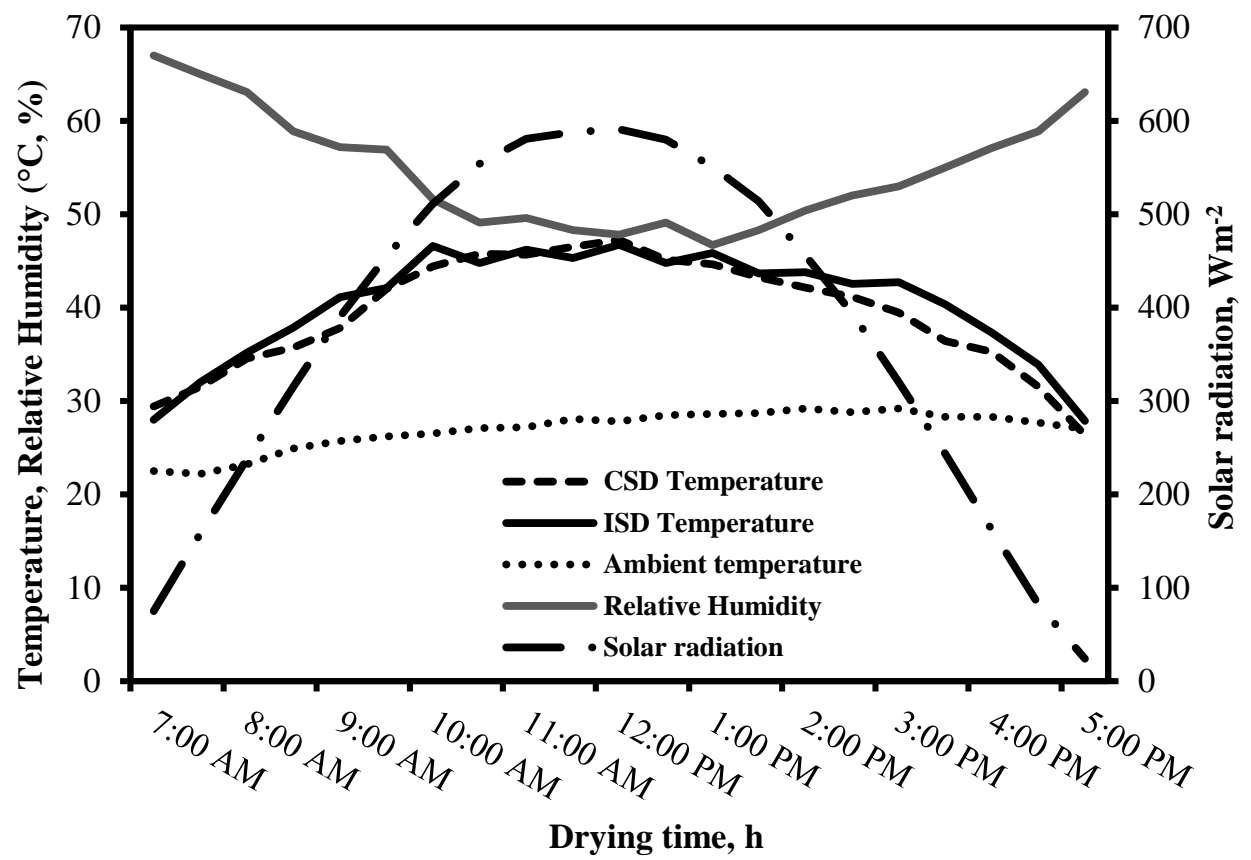

Fig. (3): Variations in air temperature, relative humidity and solar radiation during drying hours for a typical day in October 2018.

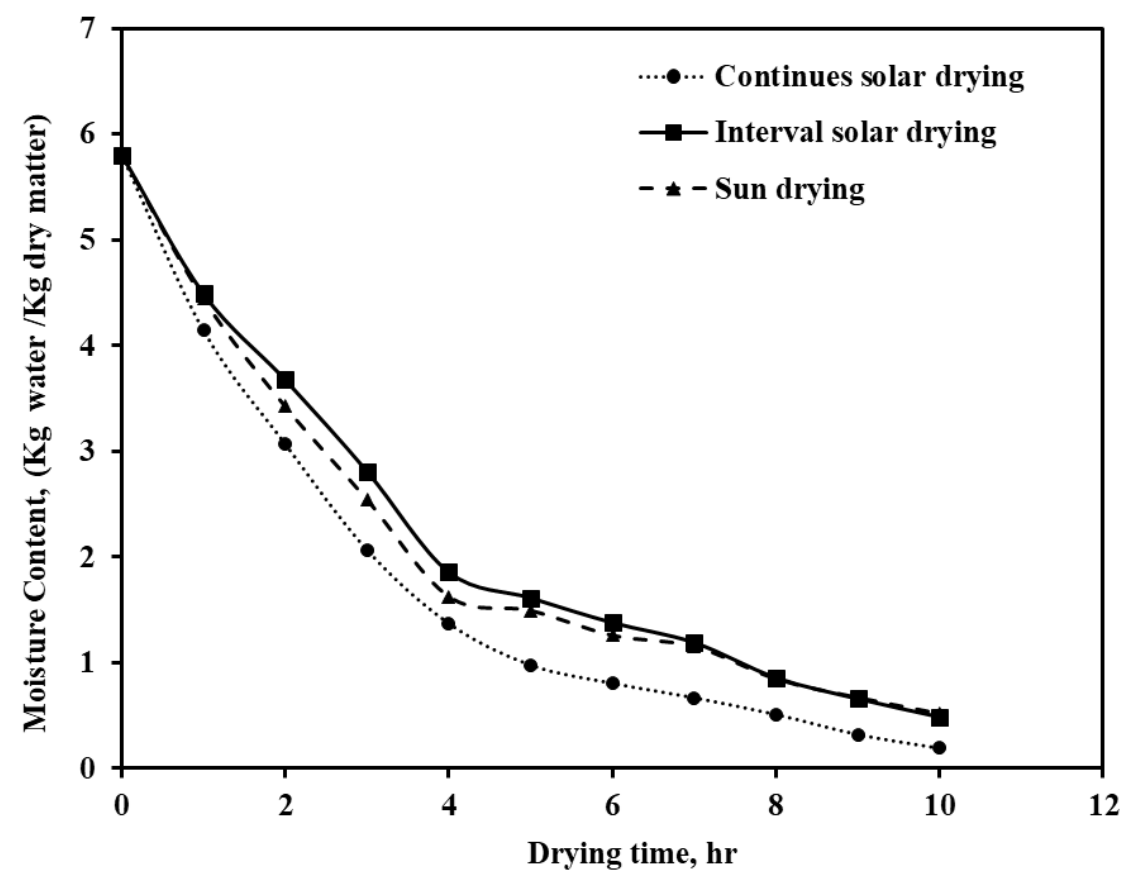

Fig. (4): Variation of moisture content with drying time of mint. 
It is clear that the mint in the solar dryer operated under the continuous forced convection dried faster than the mint in the solar dryer operated under interval forced convection and open sun drying. For instance, after 10 hours of continuous drying for mint, the final moisture content of mint in the continuous solar dryer mode was 0.19 ( $\mathrm{kg}$ water $/ \mathrm{kg}$ dry matter). While the moisture content of the mint dried in the interval solar dryer and under the open sun was the same (about $0.50 \mathrm{~kg}$ water $/ \mathrm{kg}$ dry matter). Although, the drying air temperature inside both drying units was the same, the continuous mode showed a higher drying rate. This may due to the fact that in the continuous mode the humid air inside the greenhouse dryer continuously left the dryer by the air fan and dry air entered from another side which resulted in higher drying rate. While in the intervals mode the interval time was not enough to carry out the humid air resulted from mint drying resulting in low drying rate in the greenhouse operated by the intervals mode.

The hourly drying rate of mint in the open sun, continuous and interval solar drying modes are presented in Table (2). It is clear from Table (2) and Figure 4 that at all drying modes the drying of mint occurred in the falling rate period and no constant rate period was observed. Similar trend was reported by Sallam et al. (2015) for whole mint plant and by Kadam et al. (2011) and Doymaz (2006) for mint leaves. It can be also seen in Table 2 that the drying rate of mint was much higher in the continuous solar drying mode than the other drying modes in the first 5 hours of drying. After that, the drying rate of mint in the continuous mode became less than the other drying methods until the end of the drying period. This may due to that, in the continuous solar dryer the mint dried fast and become dray after 5 hours $(0.98 \mathrm{~kg}$ water $/ \mathrm{kg}$ dry matter) resulted in low drying rate at the end of the drying time. On the contrary, the mint in the interval solar drying mode and open sun drying was still at high moisture content ( $1.5 \mathrm{~kg}$ water $/ \mathrm{kg}$ dry matter).

\section{Mathematical modeling of drying curves}

In order to normalize the drying curves, the data involving dry basis moisture content versus time were transformed into a dimensionless parameter called moisture ratio versus time (Fig. 5). 
Table (2): Moisture contents (kg water/kg dry matter) and drying rates (kg water/kg dry matter.h) of mint at specific drying times according to solar and sun drying methods.

\begin{tabular}{ccccccc}
\hline \multirow{2}{*}{$\begin{array}{c}\text { Drying } \\
\text { time, h }\end{array}$} & \multicolumn{2}{c}{ Sun drying } & \multicolumn{2}{c}{ Continues solar drying } & \multicolumn{2}{c}{$\begin{array}{c}\text { Interval solar } \\
\text { drying }\end{array}$} \\
\cline { 2 - 7 } & $\begin{array}{c}\text { Moisture } \\
\text { content }\end{array}$ & Drying rate & $\begin{array}{c}\text { Moisture } \\
\text { content }\end{array}$ & Drying rate & $\begin{array}{c}\text { Moisture } \\
\text { content }\end{array}$ & $\begin{array}{c}\text { Drying } \\
\text { rate }\end{array}$ \\
\hline 0 & 5.80 & - & 5.80 & - & 5.80 & - \\
1 & 4.44 & 1.36 & 4.14 & 1.66 & 4.49 & 1.31 \\
2 & 3.42 & 1.02 & 3.07 & 1.07 & 3.67 & 0.81 \\
3 & 2.54 & 0.88 & 2.07 & 1.00 & 2.81 & 0.87 \\
4 & 1.63 & 0.92 & 1.37 & 0.70 & 1.86 & 0.95 \\
5 & 1.49 & 0.13 & 0.98 & 0.39 & 1.61 & 0.24 \\
6 & 1.26 & 0.23 & 0.81 & 0.17 & 1.38 & 0.23 \\
7 & 1.15 & 0.10 & 0.67 & 0.14 & 1.19 & 0.19 \\
8 & 0.85 & 0.31 & 0.51 & 0.16 & 0.86 & 0.33 \\
9 & 0.67 & 0.18 & 0.32 & 0.19 & 0.66 & 0.20 \\
10 & 0.52 & 0.15 & 0.19 & 0.13 & 0.49 & 0.17 \\
\hline
\end{tabular}

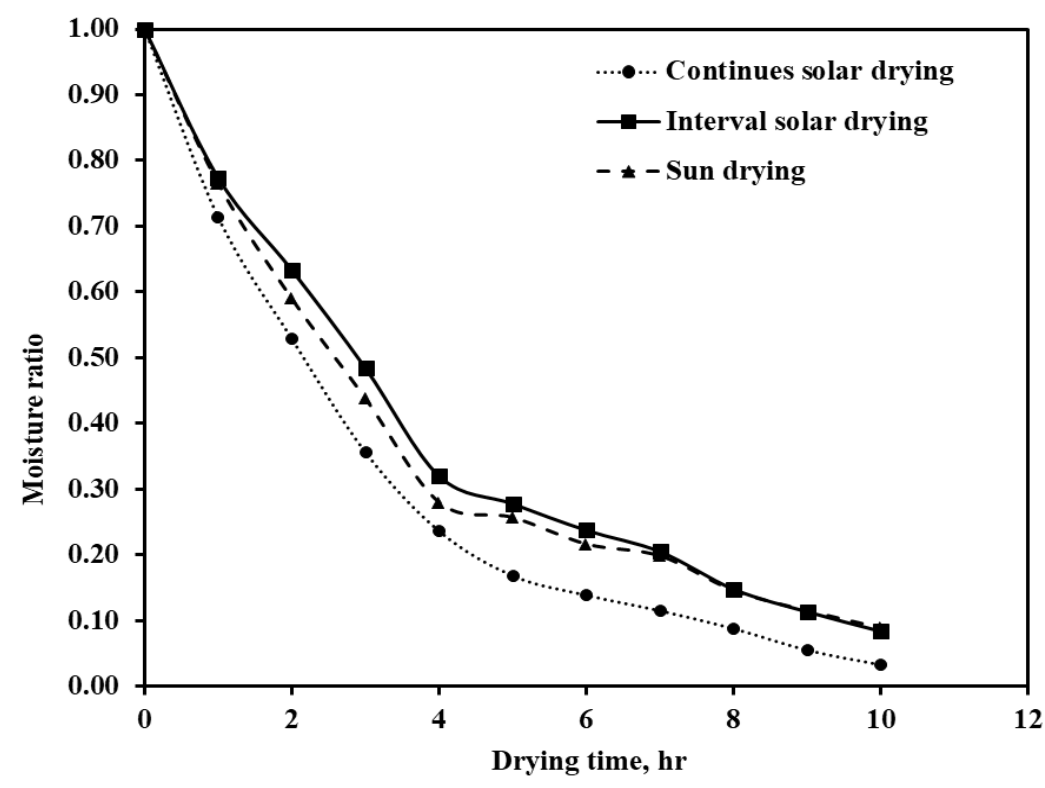

Fig. (5): Variation of moisture ratio with drying time of mint.

The moisture content data of continuous solar drying mode and the open sun drying of mint were converted to the most useful moisture ratio expression and then curve fitting computations with the drying time were carried on 10 different thin layer drying models presented in Table (1). 
The drying model coefficients and the comparison criteria used to evaluate the goodness of fit, namely the coefficient of determination $\left(\mathrm{R}^{2}\right)$, the mean relative percent error $(\mathrm{P})$ and the root mean square error (RMSE) for solar drying of mint are tabulated in Table (3). It is clear from the statistical parameters shown in Table (3) that all tested models offered a good description of the experimental data with $r^{2}$ higher than 98\% except Wang and Singh model. Similar results reported by Sallam et al. (2015). From Table (3), it can be concluded that the Modified Henderson and Pabis model gave the highest $\mathrm{R}^{2}$ and lowest $\mathrm{P}$ and RMSE values than other models. Therefore, the Modified Henderson and Pabis model could adequately describe the solar drying behavior of mint in the greenhouse solar dryer and open sun drying. There is no universal model reported in the literature as the best drying model to explain thin layer drying behavior of mint under different drying methods. For instance, Sallam et al. (2015) found that the Verma et al. model was the best model described the natural and forced convection solar drying of whole mint plant for the direct and indirect drying. For mint leaves different models reported as the best models under specific drying methods such as Wang and Singh model for indirect forced convection solar drying and open sun (Akpinar, 2010), logarithmic model for heated air-drying (Doymaz, 2006) and two-term model for tunnel dryer (Kadam et al., 2011).

Modified Henderson and Pabis model for the open sun and solar drying of mint can be written based on the estimated constants and coefficients as below:

\section{Original form:}

$$
M R=a \exp (-k t)+b \exp (-g t)+c \exp (-h t)
$$

\section{For open sun drying:}

$M R=-15880.9 * \exp (-0.2828 * t)+12853.3 * \exp (-0.2834 * t)+3028.7 * \exp (-0.2803 * t)$

\section{For solar drying:}

$$
M R=0.6048 * \exp (-0.2414 * t)-108.54 * \exp (-1.523 * t)+107.15 * \exp (-1.499 * t)
$$

In which MR is the moisture ratio and $t$ is the time (hr).

Fig. (6) illustrates the relationship between the experimental moisture ratio and the predicted values by Modified Henderson and Pabis model 
for mint drying. Strictly speaking, Modified Henderson and Pabis model provided good conformity between experimental and predicted moisture ratios of mint during drying in both open sun and greenhouse solar dryer.

Table (3): Modeling of moisture ratio according to the drying time for open sun and solar drying of mint.

\begin{tabular}{|c|c|c|c|c|c|}
\hline Model & $\begin{array}{l}\text { Drying } \\
\text { method }\end{array}$ & Model coefficients and constants & $\mathbf{R}^{2}$ & $\mathbf{p}$ & RMSE \\
\hline \multirow{2}{*}{ Newton } & Open Sun & $\mathrm{k}=0.2691$ & 0.9877 & 11.15 & 0.026 \\
\hline & Solar drying & $\mathrm{k}=0.3216$ & 0.9883 & 12.61 & 0.024 \\
\hline \multirow[t]{2}{*}{ Page } & Open Sun & $\mathrm{k}=0.2997 ; \mathrm{n}=0.9254$ & 0.9880 & 07.11 & 0.023 \\
\hline & Solar drying & $\mathrm{k}=0.3159 ; \mathrm{n}=1.0136$ & 0.9883 & 12.68 & 0.024 \\
\hline \multirow{2}{*}{ Logarithmic } & Open Sun & $\mathrm{a}=0.972 ; \mathrm{k}=0.331 ; \mathrm{c}=0.066$ & 0.9916 & 07.25 & 0.019 \\
\hline & Solar drying & $\mathrm{a}=1.0359 ; \mathrm{k}=0.3628 ; \mathrm{c}=0.0245$ & 0.9899 & 15.51 & 0.022 \\
\hline \multirow{2}{*}{ Two-term } & Open Sun & $\begin{array}{l}\mathrm{a}=0.3669 ; \mathrm{k} 0=0.1420 ; \mathrm{b}=0.7052 \\
\mathrm{k} 1=0.4496\end{array}$ & 0.9922 & 06.25 & 0.019 \\
\hline & Solar drying & $\begin{array}{l}a=1.0359 ; \mathrm{k} 0=0.3323 ; \mathrm{b}=- \\
191731.18 ; \\
\mathrm{k} 1=17.098\end{array}$ & 0.9889 & 12.68 & 0.023 \\
\hline \multirow{2}{*}{$\begin{array}{l}\text { Two-term } \\
\text { exponential }\end{array}$} & Open Sun & $\mathrm{a}=0.4428 ; \mathrm{k}=0.4362$ & 0.9902 & 06.81 & 0.021 \\
\hline & Solar drying & $\mathrm{a}=0.7420 ; \mathrm{k}=0.3484$ & 0.9885 & 12.58 & 0.024 \\
\hline \multirow{2}{*}{$\begin{array}{l}\text { Henderson and } \\
\text { Pabis }\end{array}$} & Open Sun & $\mathrm{a}=0.9650 ; \mathrm{k}=0.2590$ & 0.9863 & 09.70 & 0.025 \\
\hline & Solar drying & $\mathrm{a}=1.0257 ; \mathrm{k}=0.0836$ & 0.9889 & 12.65 & 0.023 \\
\hline \multirow{2}{*}{$\begin{array}{l}\text { Modified } \\
\text { Henderson and } \\
\text { Pabis }\end{array}$} & Open Sun & $\begin{array}{l}a=-15880.9 ; k=0.2828 ; b \\
=12853.3 ; \\
g=0.2834 ; c=3028.7 ; h=0.2803\end{array}$ & 0.9962 & 06.15 & 0.018 \\
\hline & Solar drying & $\begin{array}{l}\mathrm{a}=0.6048 ; \mathrm{k}=0.2414 ; \mathrm{b}=-108.54 \\
\mathrm{~g}=1.523 ; \mathrm{c}=107.15 ; \mathrm{h}=1.499\end{array}$ & 0.9972 & 11.57 & 0.016 \\
\hline \multirow{2}{*}{$\begin{array}{l}\text { Wang and } \\
\text { Singh }\end{array}$} & Open Sun & $a=-0.2161 ; b=0.0130$ & 0.9708 & 19.39 & 0.043 \\
\hline & Solar drying & $a=-0.2360 ; b=0.0146$ & 0.9651 & 42.15 & 0.049 \\
\hline \multirow{2}{*}{$\begin{array}{l}\text { Approximation } \\
\text { of diffusion }\end{array}$} & Open Sun & $\mathrm{a}=1.2364 ; \mathrm{k}=0.2691 ; \mathrm{b}=1.000$ & 0.9877 & 11.15 & 0.026 \\
\hline & Solar drying & $\mathrm{a}=0.0083 ; \quad \mathrm{k}=2.32 \mathrm{E}-6 ; \mathrm{b}=141696$ & 0.9888 & 13.02 & 0.024 \\
\hline \multirow{2}{*}{ Verma et al. } & Open Sun & $\mathrm{a}=0.0745 ; \mathrm{k}=0.0283 ; \mathrm{g}=0.3137$ & 0.9911 & 06.52 & 0.020 \\
\hline & Solar drying & $\mathrm{a}=1.0272 ; \mathrm{k}=0.3302 ; \mathrm{g}=3.310$ & 0.9889 & 12.65 & 0.023 \\
\hline
\end{tabular}



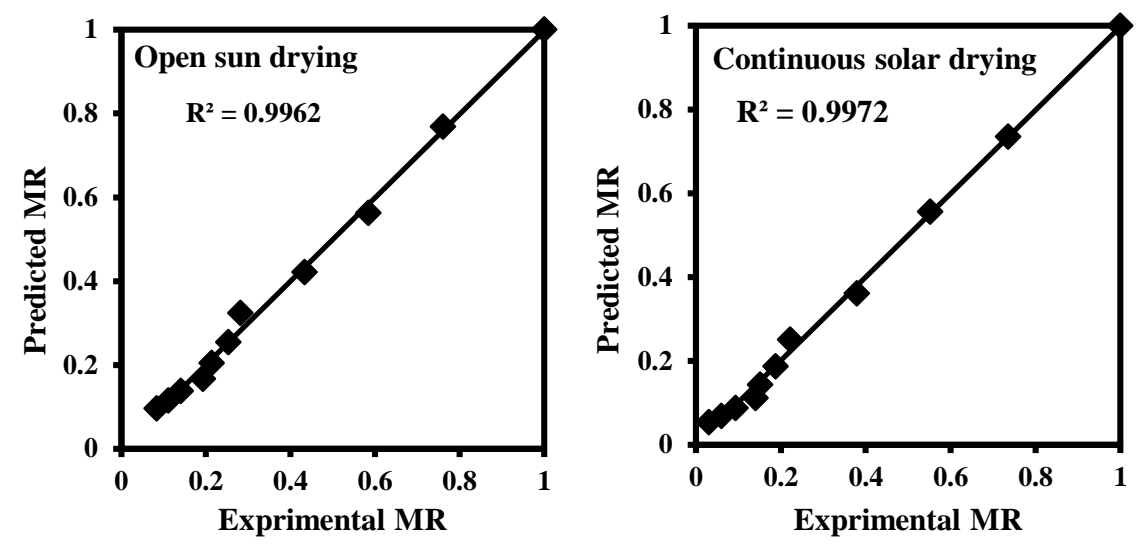

Fig. (6): Relationship between the experimental moisture ratios and the predicted values by Modified Henderson and Pabis model for mint drying

\section{CONCLUSION}

In this study, greenhouse dryer used to dry mint plant and compared with the traditional sun drying method. Two greenhouse dryers were built and operated by two modes of forced convection (continuous and intervals). The performance of two modes compared with the open sun drying. The results showed that the drying rate values of mint in the continuous solar drying mode were much higher than the corresponding values of the drying rate of mint in the interval solar drying mode and open sun drying at especially at the first 5 hours of drying. After 10 hours of continuous drying for mint, the final moisture content of mint in the continuous solar dryer mode was 0.19 ( $\mathrm{kg}$ water $/ \mathrm{kg}$ dry matter). While the moisture content of the mint dried in the interval solar dryer and under the open sun was the same (about $0.50 \mathrm{~kg}$ water $/ \mathrm{kg}$ dry matter). The drying data were fitted to ten thin layer drying models to explain the drying behavior of mint. The results showed that the Modified Henderson and Pabis model provided good conformity between experimental and predicted moisture ratios of mint during drying in both open sun and greenhouse solar dryer. The results of the study are very useful for commercial scale solar drying of mint and to optimize the drying process and to achieve a superior quality dried product.

\section{REFERENCES}

Akpinar, E. K. (2010): Drying of mint leaves in a solar dryer and under open sun: Modelling performance analyses. Energy Conversion and Management, 51, 2407-2418. 
AOAC (1990): Official methods of analysis of the association of official analytical chemists, Arlington, Virginia.

Baydar, H. and Erbas, S. (2009): Effects of harvest time and drying on essential oil properties in Lavandin (Lavandula intermedia emeric ex losiel.). Acta Horticulturae, 826: 377-382.

Corrêa, P.C.; de Oliveira, G.H.H.; Baptestini, F.M., Diniz, M.D.M.S. and da Paixão, A.A. (2012): Tomato infrared drying: Modeling and some coefficients of the dehydration process. Chilean Journal of Agricultural Research 72:262.

Doymaz, I. (2006): Thin-layer drying behaviour of mint leaves. Journal of Food Engineering, 74(3), 370-375.

El-Beltagy, A.; Gamea, G. R. and Essa, A. A. (2007): Solar drying characteristics of strawberry. Journal of food engineering, 78(2), 456-464.

El-Sebaii, A. A.; Aboul-Enein, S.; Ramadan, M. R. I. and El-Gohary, H. G. (2002): Experimental investigation of an indirect type natural convection solar dryer. Energy conversion and management, 43(16), 2251-2266.

Erbay, Z. and Icier, F. (2010): A Review of Thin Layer Drying of Foods: Theory, Modeling, and Experimental Results. Critical Reviews in Food Science and Nutrition 50(5):441-464.

Gürlek, G.; Özbalta, N. and Güngör, A. (2009): Solar tunnel drying characteristics and mathematical modelling of tomato. Journal of Thermal Science and Technology, 29, 15-23.

Hacihafizoğlu, O.; Cihan, A. and Kahveci, K. (2008): Mathematical modelling of drying of thin layer rough rice. Food and Bioproducts Processing, 86(C4):268-275.

Henderson, S. M. and Pabis, S. (1961): Grain drying theory. I. Temperature effect on drying coefficient. Journal of Agriculture Engineering Research, 6, 169-174.

Kadam, D. M. and Samuel, D. V. K. (2006): Convective flat-plate solar heat collector for cauliflower drying. Biosystems Engineering, 93(2), 189-198. 
Kadam, D. M.; Goyal, R. K.; Singh, K. K. and Gupta, M. K. (2011): Thin layer convective drying of mint leaves. Journal of Medicinal Plants Research, 5(2), 164-170.

Kishk, S. S.; ElGamal, R. A.and EIMasry, G. M. (2019): Effectiveness of recyclable aluminum cans in fabricating an efficient solar collector for drying agricultural products. Renewable Energy, 133, 307-316.

Kocabiyik, H.; Yilmaz, N.; Tuncel, N. B.; Sumer, S. K. and Burak Buyukcan, M. (2014): The effects of middle infrared radiation intensity on the quality of dried tomato products. International journal of food science \& technology, 49(3), 703-710.

Kumar, A.; Moses, S.C. and Kalay, K. (2015): A survey on the design, Fabrication and Utilization of Different Types of Foods and Vegetables Dryer. IOSR. Journal of Agriculture and Veterinary Science (IOSR-JAVS) ISSN: 2319-2380, p-ISSN: 2319-2372. 8(8): 59-68.

Mwithiga, G. and Olwal, J. O. (2005): The drying kinetics of kale (Brassica oleracea) in a convective hot air dryer. Journal of Food engineering, 71(4), 373-378.

Özbek, B. and Dadali, G. (2007): Thin-layer drying characteristics and modelling of mint leaves undergoing microwave treatment. Journal of Food Engineering, 83(4), 541-549.

Rabha, D. K.; Muthukumar, P. and Somayaji, C. (2017): Energy and exergy analyses of the solar drying processes of ghost chilli pepper and ginger. Renewable Energy, 105, 764-773.

Sallam, Y. I.; Aly, M. H.; Nassar, A. F. and Mohamed, E. A. (2015): Solar drying of whole mint plant under natural and forced convection. Journal of advanced research, 6(2), 171-178.

Santos, B.; Queiroz, M. and Borges, T. (2005): A solar collector design procedure for crop drying. Brazilian Journal of Chemical Engineering 22:277-284.

Sekyere, C. K. K.; Forson, F. K. and Adam, F. W. (2016): Experimental investigation of the drying characteristics of a 
mixed mode natural convection solar crop dryer with back up heater. Renewable Energy, 92, 532-542.

Sharaf-Eldeen, Y. I.; Blaisdell, J. L. and Hamdy, M. Y. (1980): A model for ear corn drying. Transactions of the ASAE, 23, 12611271.

Soysal, Y. (2005): Mathematical modeling and evaluation of microwave drying kinetics of mint (Mentha spicata L.). Journal of Applied Sciences, 5(7), 1266-1274.

Sreekumar A., Manikantan P. and Vijayakumar K. (2008): Performance of indirect solar cabinet dryer. Energy Conversion and Management 49:1388-1395.

Tarhan, S.; Telci, İ.; Tuncay, M. T. and Polatci, H. (2010): Product quality and energy consumption when drying peppermint by rotary drum dryer. Industrial Crops and Products, 32(3), 420427.

Verma, L. R.; Bucklin, R. A.; Endan, J. B. and Wratten, F. T. (1985): Effects of drying air parameters on rice drying models. Transactions of the ASAE, 28(1), 296-0301.

Wang, C. Y. and Singh, R. P. (1978): A single layer drying equation for rough rice. ASAE Paper No: 78-3001, ASAE, St. Joseph, MI.

Yaldiz, O. and Ertekin, C. (2001): Thin layer solar drying some different vegetables. Drying Technology 19:583-597.

الملخص العربى

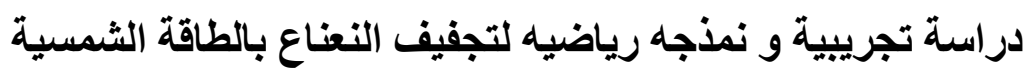

سامح سعيد كثك '، سلاف سيد عبد الرحيمَ و رمضان عبد الحميد الجملَ

أجري هذا البحث بقسم الهندسة الزر اعيـة ـ كلية الزر اعـة ـ جامعـة قناة السويس الإسماعيلية،

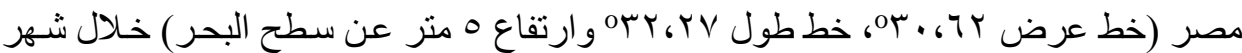

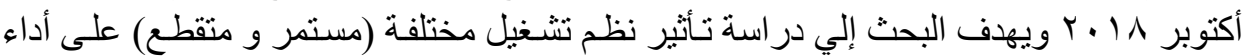

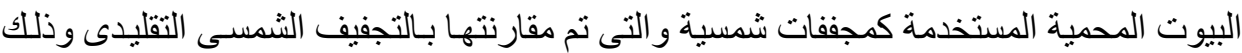

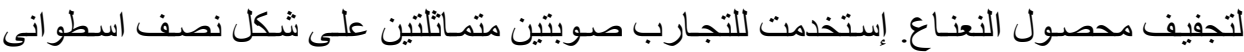
بمساحة ارضية ب مَّ وتم تغطينها بطبقة و احدة من البولى ايثيلين. 


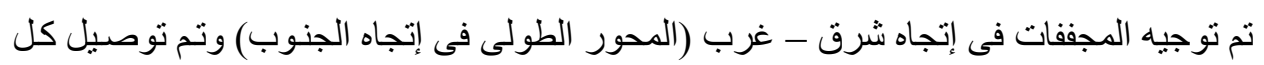

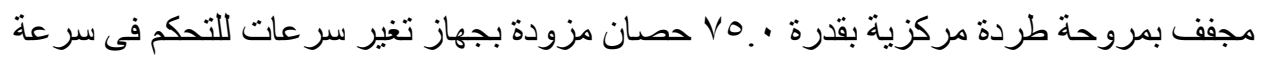

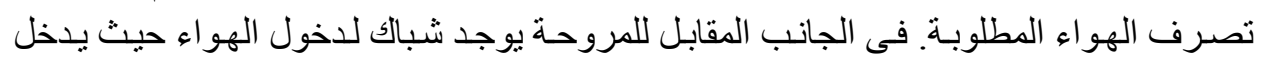

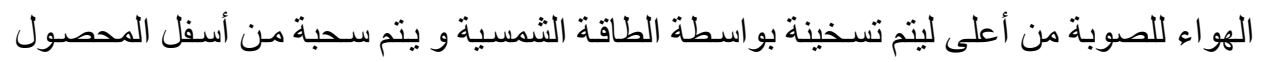

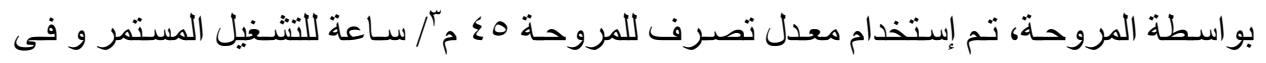

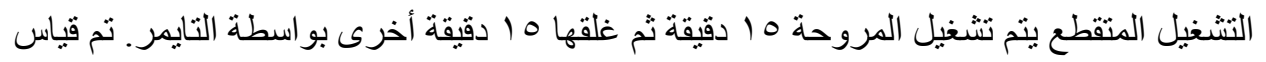

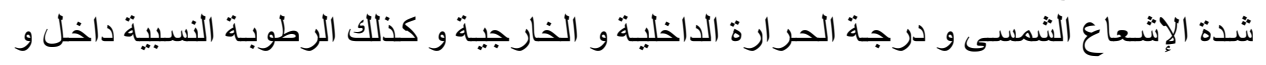

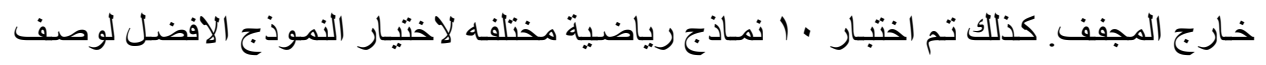
عملية التجفيف الثنمسى للنعناع. وقد أوضحت النتائج مايلي:

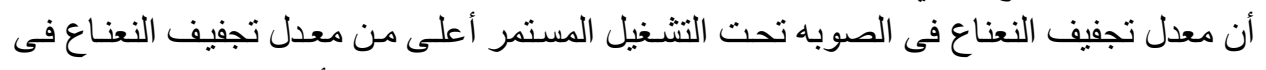

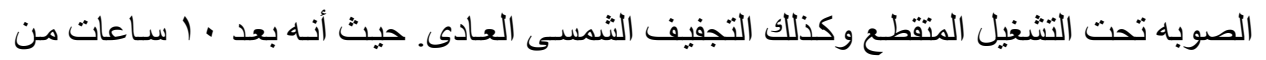

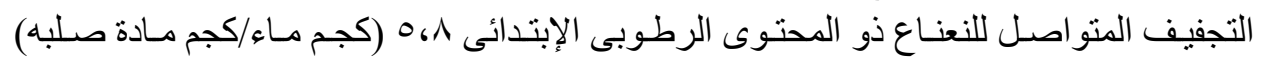

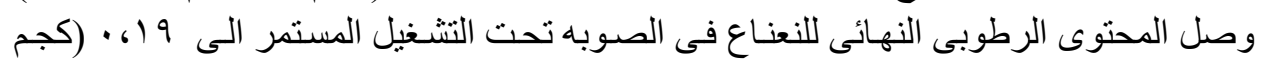

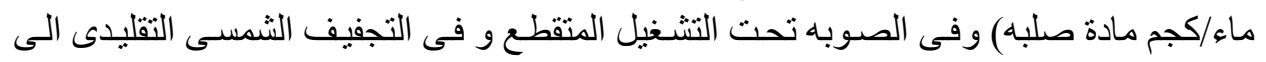

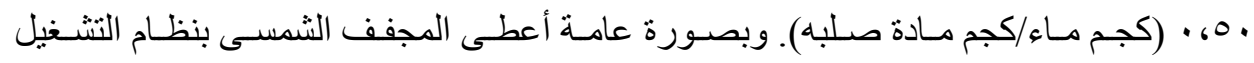

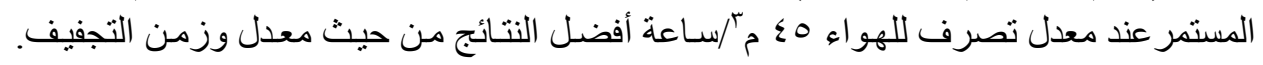
كذللك أعطى نموذج هندرسون وبابيس المعدل ) Modified Henderson and Pabis أفضل وصف لعملية التجفيف الثمسى للنعناع بأعلى معامل إرتباط و أقل مقدار للخطأ. (model 